Check for updates

Cite this: RSC Adv., 2018, 8, 9161

\title{
Improving the cycling stability of lithium-sulfur batteries by hollow dual-shell coating $\dagger$
}

\begin{abstract}
Jianhua Zhang, Rujia Zou, (D) * Qian Liu, Shu-ang He, Kaibing Xu and Junqing Hu (D) *
Herein, a novel hybrid $\mathrm{S} \mathrm{MnO}_{2} \mathrm{aC}$ nanosphere, comprising sulfur nanoparticles encapsulated by a $\mathrm{MnO}_{2} \mathrm{aC}$ hollow dual-shell, is reported. Benefiting from a conductive $\mathrm{C}$ outer layer, the $\mathrm{S}_{\mathrm{MnO}} \mathrm{OCC}_{2}$ hybrid nanosphere provided highly efficient pathways for fast electron/ion transfer and sufficient free space for the expansion of the encapsulated sulfur nanoparticles. Moreover, the dual-shell composed of a $\mathrm{MnO}_{2}$ inner layer and a $\mathrm{C}$ outer layer coating on $\mathrm{S}$ not only improved the efficacious encapsulation of sulfur, but also significantly suppressed the dissolution of polysulfides during cycling. As a result, the $\mathrm{S} a \mathrm{MnO}_{2} \mathrm{aC}$ electrode shows high capacity, high coulombic efficiency and excellent cycling stability. The $\mathrm{S} \mathrm{MnO}_{2} \mathrm{aC}$ cathode delivered a discharge capacity of $593 \mathrm{~mA} \mathrm{~h} \mathrm{~g}^{-1}$ in the fourth cycle and was able to maintain $573 \mathrm{~mA} \mathrm{~h} \mathrm{~g}^{-1}$ after 100 charge-discharge cycles at $1.0 \mathrm{C}$, corresponding to a capacity retention of $96.6 \%$
\end{abstract}

Received 11th December 2017 Accepted 16th February 2018

DOI: 10.1039/c7ra13235b

rsc.li/rsc-advances decrease the mechanical integrity and the stability of S-composite structures during charge and discharge processes.

Currently, most efforts to tackle these issues are based on S-composite cathode architectures in Li-S batteries. A commonly employed strategy is using high-surface-area carbon materials, such as hollow carbon structures, porous carbon, and graphene/graphene oxides. ${ }^{\mathbf{1 0 - 1 2}}$ Though recognized as materials with great potential for improving electrochemical performance, $\mathrm{C} / \mathrm{S}$ composite structures cannot sustain prolonged-life cycling due to the surface polarity difference between carbon and lithium polysulfides. Recently, polar materials, metal oxides and metal sulfides were employed to effectively suppress the polysulfides-shuttle via creating a relatively strong chemical interaction with dissolvable polysulfides, thus effectively confining them within the S-composite cathode, which significantly improved the cycling stability. ${ }^{\mathbf{1 3 , 1 4}}$ However, despite the significant advances in the use of these polar materials, S/polar materials' composite structures cannot quickly transfer electrons and ions in the electrodes due to the increase in internal resistance of the battery, which causes rate capability decay and low specific capacity, particularly under large current densities. Recently, a new way to solve these problems of $\mathrm{Li}-\mathrm{S}$ batteries using S/C/polar materials-based composites was put forward, which could result in a more stable performance. ${ }^{15-18}$ These S/C/polar materials-based composites not only confine the shuttle effect, but also increase the conductivity of the entire cathode, easily prolonging the cycle life of $\mathrm{Li}-\mathrm{S}$ batteries. However, S/C/polar composites were always imperfectly designed as pores or open structures cannot effectively prevent the loss of polysulfides into the electrolyte, which could help obtain an improved but diminished cycle..$^{15-17,19}$ Moreover, the outermost coating layer of polar materials often has high
State Key Laboratory for Modification of Chemical Fibers and Polymer Materials, College of Materials Science and Engineering, Donghua University, Shanghai 201620,China.E-mail: rjzou@dhu.edu.cn; hu.junqing@dhu.edu.cn

$\uparrow$ Electronic supplementary information (ESI) available. See DOI: 10.1039/c7ra13235b 
resistance compared with carbon materials, which can block the transport of electrons among active materials., ${ }^{\mathbf{9} 20}$ Therefore, it is still a great challenge to design innovative nanostructures for efficacious encapsulation of sulfur to control polysulfide dissolution and obtain long life-cycling stability at high current densities.

Herein, a rational design and hybrid structure with sulfur nanoparticles filled in $\mathrm{MnO}_{2} @ \mathrm{C}$ hollow dual-shell spheres to form $\mathrm{S} @ \mathrm{MnO}_{2} @ \mathrm{C}$ hybrid nanospheres is reported. This $\mathrm{S} @ \mathrm{MnO}_{2} @ \mathrm{C}$ hybrid nanosphere has several apparent advantages. First, hollow $\mathrm{C}$ nanospheres with high conductivity provide highly efficient pathways for fast electron/ion transfer during long-term cycling. Second, the dual-shell composed of an internal $\mathrm{MnO}_{2}$ coating layer and an external hollow C coating layer can provide chemical adsorption to polysulfides and effectively prevent polysulfides from rapidly dissolving into the electrolyte. Third, the additional void after sulfur introduction provides sufficient free space for the expansion of encapsulated sulfur nanoparticles. The special material composition and structure design endows the $\mathrm{S} @ \mathrm{MnO}_{2} @ \mathrm{C}$ electrode with a much improved capacity, high coulombic efficiency and an excellent cycling stability.

\section{Experimental}

\subsection{Materials synthesis}

All chemical agents used in this experiment were commercially purchased and used without further purification.

2.1.1 Synthesis of $\mathrm{SiO}_{2}$ nanospheres. $\mathrm{SiO}_{2}$ nanospheres were prepared by the hydrolysis of TEOS with the help of $\mathrm{NH}_{4} \mathrm{OH}$. First, $10 \mathrm{~mL} \mathrm{NH} \mathrm{NH}_{4} \mathrm{OH}(28 \mathrm{wt} \%$ ), $20 \mathrm{~mL}$ distilled water and $20 \mathrm{~mL}$ absolute ethanol were thoroughly mixed through magnetic stirring for $30 \mathrm{~min}$. Then, $60 \mathrm{~mL}$ ethanol containing $5 \mathrm{~mL}$ TEOS was added into the mixture and then, this mixture was vigorously stirred for $12 \mathrm{~h}$. The white turbid suspension was centrifuged with ethanol for 3 times and with water for the final time to obtain the $\mathrm{SiO}_{2}$ spheres.

2.1.2 Synthesis of $\mathrm{SiO}_{2} @ \mathrm{MnO}_{2}$. The freshly prepared $\mathrm{SiO}_{2}$ nanospheres were re-dispersed into $30 \mathrm{~mL} 0.03 \mathrm{M} \mathrm{KMnO}_{4}$ aqueous solution in a round-bottom flask. After agitating for one night, the flask was placed at $70{ }^{\circ} \mathrm{C}$ in water bath for $6 \mathrm{~h}$. $\mathrm{SiO}_{2} @ \mathrm{MnO}_{2}$ were collected by washing with distilled water for 3 times.

2.1.3 Synthesis of $\mathrm{MnO}_{2}$ @C hollow spheres. Initially, $100 \mathrm{mg} \mathrm{SiO} \mathrm{S}_{2} @ \mathrm{MnO}_{2}$ powder was uniformly dispersed into Tris$\mathrm{HCl}$ buffer solution $(100 \mathrm{~mL}, \mathrm{pH}=8.5)$ and then, dopamine (DA) $(50 \mathrm{mg}$ ) was added into the suspension and stirred for $6 \mathrm{~h}$. The precipitate obtained on centrifugation with water and drying at $60{ }^{\circ} \mathrm{C}$ was denoted as $\mathrm{SiO}_{2} @ \mathrm{MnO}_{2} @ \mathrm{PDA}$. Dried $\mathrm{SiO}_{2} @ \mathrm{MnO}_{2} @ P D A$ powder was carbonized under $\mathrm{H}_{2}$ atmosphere at $700{ }^{\circ} \mathrm{C}$ for $3 \mathrm{~h}$ to form $\mathrm{SiO}_{2} @ \mathrm{MnO}_{2} @ \mathrm{C}$. The $\mathrm{SiO}_{2}$ core of $\mathrm{SiO}_{2} @ \mathrm{MnO}_{2} @ \mathrm{C}$ was then removed by agitating at $80{ }^{\circ} \mathrm{C}$ with $4 \mathrm{M} \mathrm{NaOH}$ aqueous solution for $4 \mathrm{~h} . \mathrm{MnO}_{2} @ \mathrm{C}$ hollow spheres were obtained by centrifuging several times with distilled water and drying at $60{ }^{\circ} \mathrm{C}$ in a vacuum oven.

2.1.4 Synthesis of $\mathbf{S} @ \mathrm{MnO}_{2} @ \mathrm{C}$. Sublimed sulfur and dried $\mathrm{MnO}_{2}$ @C powder were mixed with a desired weight ratio and sealed in a Teflon reactor full of argon. The reactor was heated to $155{ }^{\circ} \mathrm{C}$ and kept at this temperature for $36 \mathrm{~h}$.

2.1.5 Synthesis of $\mathrm{MnO}_{2} / \mathrm{S}$. Initially, $426.6 \mathrm{mg} \mathrm{KMnO}_{4}$ was dissolved in $90 \mathrm{~mL}$ distilled water. After sufficiently dissolving $\mathrm{KMnO}_{4}, 1 \mathrm{~mL}$ absolute ethanol was added into the solution and stirred for $12 \mathrm{~h} . \mathrm{MnO}_{2}$ nanoflowers were obtained by centrifuging with water for several times. Then, the dark brown sediments were dispersed into $4 \mathrm{M} \mathrm{NaOH}$ aqueous solution and stirred at $80{ }^{\circ} \mathrm{C}$ for $4 \mathrm{~h}$, followed by washing with sufficient amount of water. After drying in a vacuum oven, $\mathrm{MnO}_{2} / \mathrm{S}$ was prepared by the same method with $\mathrm{S} @ \mathrm{MnO}_{2} @ \mathrm{C}$.

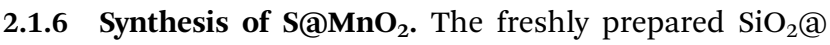
$\mathrm{MnO}_{2}$ nanospheres were dispersed into $4 \mathrm{M} \mathrm{NaOH}$ aqueous solution and stirred at $80{ }^{\circ} \mathrm{C}$ for $4 \mathrm{~h}$, followed by washing with sufficient amount of water. $\mathrm{MnO}_{2}$ hollow spheres-powder was obtained after vacuum freeze-drying the $\mathrm{SiO}_{2} @ \mathrm{MnO}_{2}$ nanospheres. $\mathrm{S} @ \mathrm{MnO}_{2}$ was prepared by the same method with $\mathrm{S} @ \mathrm{MnO}_{2} @ \mathrm{C}$.

2.1.7 Synthesis of $\mathrm{S} @ \mathrm{C}$. Dried $\mathrm{SiO}_{2}$ nanospheres were dispersed into Tris-HCl buffer solution $(100 \mathrm{~mL}, \mathrm{pH}=8.5)$ and then, dopamine (DA) (50 mg) was added into the suspension and stirred for $6 \mathrm{~h}$. A black powder was obtained on centrifugation with water and drying at $60{ }^{\circ} \mathrm{C}$. Following this, the black powder was carbonized under $\mathrm{H}_{2}$ atmosphere at $700{ }^{\circ} \mathrm{C}$ for $3 \mathrm{~h}$ to form $\mathrm{SiO}_{2} @ \mathrm{C}$. Then, $\mathrm{SiO}_{2} @ \mathrm{C}$ powder was re-dispersed into $4 \mathrm{M} \mathrm{NaOH}$ aqueous solution at $80{ }^{\circ} \mathrm{C}$ to remove $\mathrm{SiO}_{2}$. Carbon hollow spheres were obtained by centrifuging several times with distilled water and drying at $60{ }^{\circ} \mathrm{C}$ in a vacuum oven. S@C was prepared by the same method using S@MnO $\mathrm{M}_{2} @ \mathrm{C}$.

\subsection{Materials characterization}

The morphologies and microstructures were characterized by FE-SEM (Field Emission Scanning Electron Microscope, Hitachi S-4800 equipped with an energy-dispersive X-ray spectrometer) and FE-TEM (Field Emission Scanning Electron Microscope, JEM-2100F). The spectrum recorded using an X-ray Diffractometer (D/MAX-2550VB+) was used to confirm the ingredients and the phase of the compositions. XPS data were obtained using an EALA Lab MKII spectrometer with an excitation source of $\mathrm{Mg}-\mathrm{K} \alpha$ radiation. The weight ratio of sulfur was examined by TGA (Thermal Gravimetric Analyzer TG 209 F1) under nitrogen flow with a heating rate of $20^{\circ} \mathrm{C} \mathrm{min}^{-1}$. The carbon content of the $\mathrm{MnO}_{2} @ \mathrm{C}$ hollow sphere was evaluated by Elemental Analysis (Vario EL III).

\subsection{Electrochemical measurements}

Powder composed of active material (S@MnO $2 @ \mathrm{C}, \mathrm{MnO}_{2} / \mathrm{S}$ ), carbon black and poly(vinylidene fluoride) (PVDF) binder with a weight ratio of $7: 2: 1$ was sufficiently mixed in an appropriate amount of $N$-methyl-2-pyrrolidone (NMP) to form a homogeneous slurry. The typical loading density of active materials of S@ $\mathrm{MnO}_{2} @ \mathrm{C}$ was 1.2-1.4 mg cm ${ }^{-2}$. The slurry was then coated onto the aluminum foil uniformly before drying in a vacuum oven of $60{ }^{\circ} \mathrm{C}$ for $12 \mathrm{~h}$ to form the working electrode. In an argon-filled glove box, 2032-type coin cells were assembled and lithium foil was used as the counter electrode. Then, $1 \mathrm{M}$ 
LiPF $_{6}$ dissolved in 1:1 v/v DOL and DME containing $0.5 \mathrm{M}$ $\mathrm{LiNO}_{3}$ was used as the electrolyte and Celgard 2400 was the separator. Galvanostatic discharge-charge tests were carried out on a LANDHE Measurement System (Landhe, Wuhan, China) between cutoff voltages of $2.8 \mathrm{~V}$ and $1.7 \mathrm{~V}\left(v s . \mathrm{Li} / \mathrm{Li}^{+}\right)$. Current densities and specific capacities were both calculated based on the sulfur loading on the working electrode $(1 \mathrm{C}=$ $1672 \mathrm{~mA} \mathrm{~h} \mathrm{~g}^{-1}$ ). Electrochemical impedance spectroscopy was conducted by testing at $5 \mathrm{mV}$ ac oscillation amplitude over the frequency range of $100 \mathrm{kHz}$ to $100 \mathrm{mHz}$. CV measurements were conducted at the scan rate of $0.1 \mathrm{mV} \mathrm{s}^{-1}$ over the potential range of 1.7-2.8 $\mathrm{V}$ on an electrochemical workstation (Metrohm Autolab).

\section{Results and discussion}

The synthesis of the $\mathrm{S} @ \mathrm{MnO}_{2} @ \mathrm{C}$ hybrid nanosphere is illustrated in Fig. 1a (see the Experimental section for the details). Uniform $\mathrm{SiO}_{2}$ nanospheres were prepared by the hydrolysis of TEOS with the assistance of $\left(\mathrm{NH}_{3}\right) \cdot \mathrm{H}_{2} \mathrm{O}$. The $\mathrm{SiO}_{2}$ nanospheres were coated with a thin $\mathrm{MnO}_{2}$ layer, which acts as a chemical adsorption layer and prevents the polysulfides from diffusing
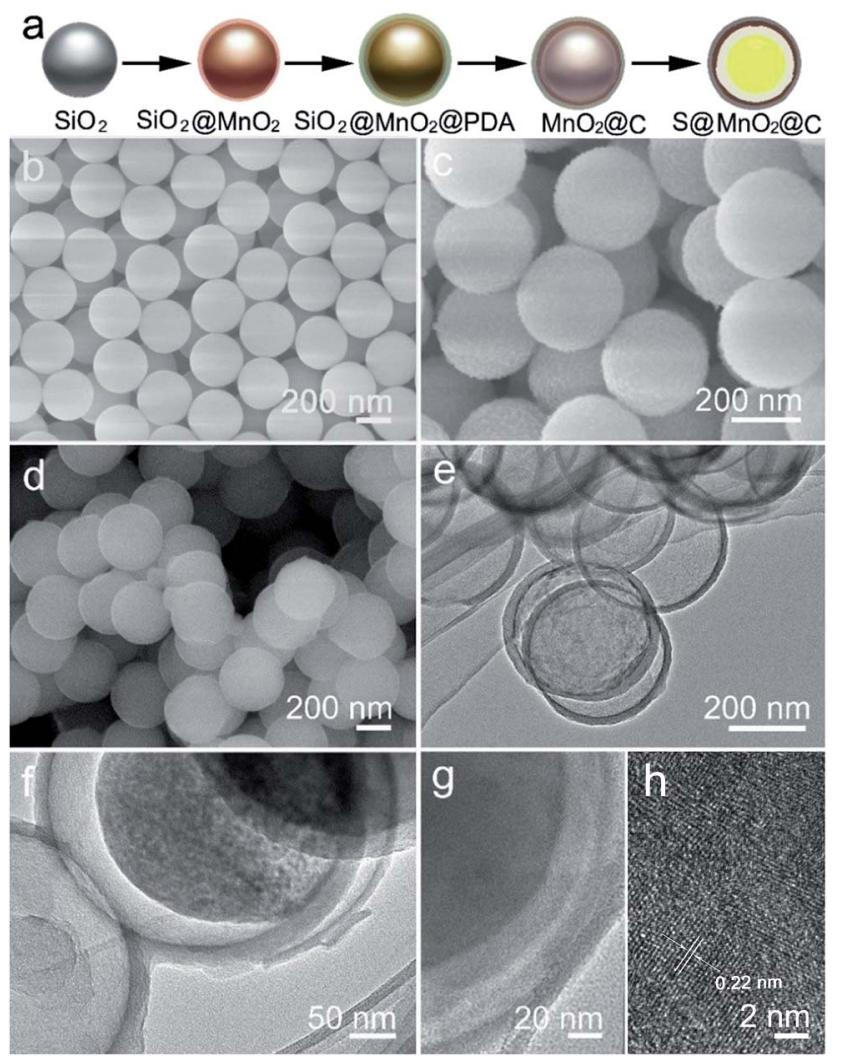

Fig. 1 (a) Schematic illustrations showing the fabrication of the $\mathrm{S} \mathrm{CMnO}_{2} \mathrm{OC}$ hybrid nanosphere. (b) SEM image of $\mathrm{SiO}_{2}$ nanospheres. (c) SEM image of the $\mathrm{SiO}_{2}\left(\mathrm{aMnO}_{2}\right.$ hybrid nanosphere. (d) SEM image of the $\mathrm{SiO}_{2} @ \mathrm{MMnO}_{2} @ \mathrm{aPDA}$ hybrid nanospheres. (e) TEM image of the $\mathrm{MnO}_{2} \mathrm{aC}$ hybrid nanospheres. (f) TEM image of the $\mathrm{S}_{\mathrm{aMnO}} \mathrm{aC}$ hybrid nanospheres. (g) High magnification TEM image of the $\mathrm{S}\left(\mathrm{MnO}_{2} \mathrm{CC}\right.$ hybrid nanospheres. (h) HRTEM image of the $\mathrm{S} \mathrm{MnO}_{2} \mathrm{QC}$ hybrid nanospheres. into the electrolyte. Then, a thin PDA layer was coated on $\mathrm{SiO}_{2} @ \mathrm{MnO}_{2}$ nanospheres as the carbon precursor. After carbonization under $\mathrm{H}_{2}$ atmosphere and removal of $\mathrm{SiO}_{2}$ with $\mathrm{NaOH}$, hollow $\mathrm{MnO}_{2}$ nanospheres coated with a hollow carbon layer to form $\mathrm{MnO}_{2} @ \mathrm{C}$ dual-shell hollow spheres were obtained. Finally, sulfur was introduced into the $\mathrm{MnO}_{2} @ \mathrm{C}$ via a melt-diffusion strategy to fabricate the $\mathrm{S} @ \mathrm{MnO}_{2} @ \mathrm{C}$ hybrid nanosphere. As shown in Fig. 1b, $\mathrm{SiO}_{2}$ nanospheres were obtained and with uniform size of $\sim 310 \mathrm{~nm}$. After coating with $\mathrm{MnO}_{2}$ layer as a polar chemical adsorption layer, the average diameter of the $\mathrm{SiO}_{2} @ \mathrm{MnO}_{2}$ hybrid nanosphere increased to $\sim 330 \mathrm{~nm}$ (Fig. 1c), indicating that a thin layer of $\mathrm{MnO}_{2}$ was formed. The $\mathrm{SiO}_{2} @ \mathrm{MnO}_{2} @ \mathrm{PDA}$ maintained its spherical shape after PDA-layer coating as shown in Fig. 1d. After carbonization and $\mathrm{SiO}_{2}$ etching by $\mathrm{NaOH}$, the hollow dual-shell $\mathrm{MnO}_{2} @ \mathrm{C}$ still retained their spherical morphology (Fig. 1e). The elemental analysis suggests that the carbon content in $\mathrm{MnO}_{2} @ \mathrm{C}$ was $\sim 43.78 \%$. The TEM image also reveals that the diameter of the $\mathrm{MnO}_{2} @ \mathrm{C}$ hollow sphere is $\sim 370 \mathrm{~nm}$, which can provide sufficient free-space for high loading of sulfur. Sulfur was introduced into the $\mathrm{MnO}_{2} @ \mathrm{C}$ to form $\mathrm{S} @ \mathrm{MnO}_{2} @ \mathrm{C}$ hybrid nanospheres through a traditional melt-diffusion method as shown in Fig. 1f and S1. $\dagger$ The $\mathrm{S} @ \mathrm{MnO}_{2} @ \mathrm{C}$ hybrid nanosphere effectively retained its morphology after the melt-diffusion reaction, exhibiting the firmness of the structure (Fig. S1 $\dagger$ ). The apparent brightness contrast observed in Fig. 1f demonstrates the extra space available after the infiltration of $\mathrm{S}$, which effectively buffers the volume expansion of sulfur during lithiation and delithiation. ${ }^{21}$ Thermogravimetric analysis curve is presented in Fig. S2, $\uparrow$ which shows high sulfur loading $(\sim 60 \%)$ in the S@ $\mathrm{MnO}_{2} @ \mathrm{C}$ hybrid nanosphere. The high magnification TEM image further uncovers the detailed structure and clearly distinguishes uniform hollow dual-shell of carbon and $\mathrm{MnO}_{2}$ layer coated on the S-core for the $\mathrm{S} @ \mathrm{MnO}_{2} @ \mathrm{C}$ hybrid nanosphere (Fig. 1g). The elemental distribution of the $\mathrm{S} @ \mathrm{MnO}_{2} @ \mathrm{C}$ hybrid nanosphere was detected through X-ray mapping with a matching TEM image, which revealed that $\mathrm{C}, \mathrm{Mn}, \mathrm{O}$ and $\mathrm{S}$ are uniformly distributed in the core (S) and the shell (C, Mn, O) regions, which is in accordance with the TEM image (Fig. S3 $\dagger$ ). The thickness of the dual-shell layer is $\sim 20 \mathrm{~nm}$. As shown in Fig. 1h, the high resolution transmission electron microscope (HRTEM) image of the $\mathrm{MnO}_{2}$ layer shows a lattice spacing of $0.22 \mathrm{~nm}$, which can be indexed to the (201) planes of birnessite $\delta-\mathrm{MnO}_{2}$.

In order to further understand the structure characterization, X-ray diffraction (XRD) and X-ray photoelectron spectroscopy (XPS) were utilized to analyze the synthesized hybrid nanospheres. As shown in Fig. 2a, the XRD pattern of the asprepared $\mathrm{MnO}_{2} @ \mathrm{C}$ hierarchical microspheres is characterized (higher panel of Fig. 2a). Three sharp and intense peaks at around $35.1^{\circ}, 40.9^{\circ}$ and $59.1^{\circ}$ can be respectively well-indexed to the (111), (200) and (220) planes of birnessite $\mathrm{MnO}_{2}$ (JCPDS-431456, lower panel of Fig. 2a). No impure phase of other manganese oxides was detected, indicating that phase pure birnessite $\mathrm{MnO}_{2}$ was obtained. The absence of carbon diffraction peaks may result from its low content and crystallization structure. ${ }^{16,22}$ As shown in Fig. 2b, diffused sulfur in the 

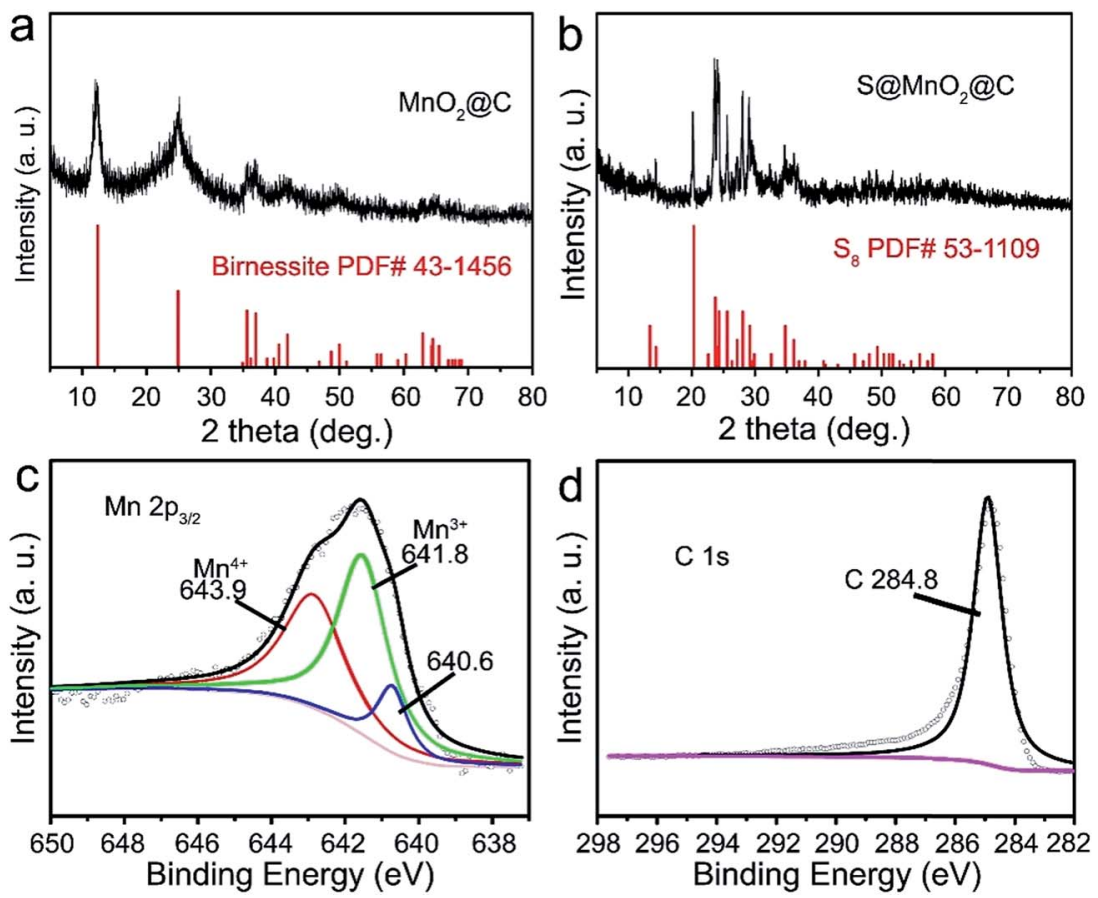

Fig. 2 (a) XRD patterns of $\mathrm{MnO}_{2}$ (aC hybrid nanospheres (upper panel) and JCPDS card ( $\mathrm{MnO}_{2}$, no. 43-1456) (lower panel). (b) XRD patterns of $\mathrm{S}\left(\mathrm{MnO}_{2} \mathrm{aC}\right.$ hybrid nanospheres (upper panel) and JCPDS card ( $\mathrm{S}_{8}$, no. 53-1109) (lower panel). XPS spectra of S@MnO 2 aC hybrid nanospheres: (c) $M n 2 p_{3 / 2}$ and (d) C $1 \mathrm{~s}$.

$\mathrm{S} @ \mathrm{MnO}_{2} @ \mathrm{C}$ hybrid nanospheres (higher panel of Fig. 2b) showed the same crystal structure of sulfur indexed in JCPDS53-1109 as displayed in the XRD pattern (lower panel of Fig. 2b). XPS survey assured the existence of Mn (Fig. 2b) and C (Fig. 2c). Binding energies at $643.9 \mathrm{eV}$ and $641.8 \mathrm{eV}$ were ascribed to the chemical state of $\mathrm{Mn}^{4+}$ and $\mathrm{Mn}^{3+}$, respectively. ${ }^{23,24}$ In addition, a peak appeared in the lower binding energy region, which can be attributed to the Mn-S bonds. ${ }^{25}$ There is no new peak in the $\mathrm{C} 1 \mathrm{~s}$ spectra, indicating no interaction between $\mathrm{C}$ and $\mathrm{S}$.

The electrochemical test of the electrodes was performed in a coin-type cell and the lithium foil was used as the counter electrode. The cell was tested between the cut-off voltage of 1.7$2.8 \mathrm{~V}\left(v s . \mathrm{Li} / \mathrm{Li}^{+}\right)$. Fig. 3a shows the cyclic voltammetry (CV) curves of the $\mathrm{S} @ \mathrm{MnO}_{2} @ \mathrm{C}$ cathode for the first five cycles at $0.1 \mathrm{mV} \mathrm{s}^{-1}$. The $\mathrm{CV}$ curves show two reduction peaks appearing at 2.3 and $2.05 \mathrm{~V}$. The broad reduction peak at $2.3 \mathrm{~V}$ is attributed to the reduction of $\mathrm{S}_{8}$ to intermediate polysulfides $\left(\mathrm{Li}_{2} \mathrm{~S}_{x}, 4 \leq x\right.$ $\leq 8)$ and further reduction to insoluble $\mathrm{Li}_{2} \mathrm{~S}_{2}$ or $\mathrm{Li}_{2} \mathrm{~S}^{26,27} \mathrm{~A}$ strong oxidation peak at $2.38 \mathrm{~V}$ corresponds to the delithiation process from $\mathrm{Li}_{2} \mathrm{~S} / \mathrm{Li}_{2} \mathrm{~S}_{2}$ to $\mathrm{Li}_{2} \mathrm{~S}_{x}$ and eventually to $\mathrm{S}_{8} \cdot{ }^{28,29}$ In the following cycles, the intensities of reduction and oxidation peaks remain almost unchanged, suggesting an excellent reversibility of the cycling process. Moreover, compared with the $\mathrm{S} @ \mathrm{C}$ cathode in previous reports ${ }^{29-32}$ the $\mathrm{CV}$ curve of the $\mathrm{S} @ \mathrm{MnO}_{2} @ \mathrm{C}$ cathode shows a distinct positive shift in the reduction peaks and a negative shift in the oxidation peaks. This implies a strong electrocatalytic effect and an improved polysulfide redox kinetics resulting from the $\mathrm{MnO}_{2}$ layer inside the $\mathrm{S} @ \mathrm{MnO}_{2} @ \mathrm{C}$ hybrid nanospheres, ${ }^{33,34}$ indicating the successful creation of relatively strong chemical interactions with $\mathrm{Li}_{2} \mathrm{~S}_{x}(x=4-8)$. Fig. $3 \mathrm{~b}$ shows the first cycle dischargecharge voltage profile of the $\mathrm{S} @ \mathrm{MnO}_{2} @ \mathrm{C}$ cathode at the current density of $0.2 \mathrm{C}$. In the discharge-charge cycle, two potential plateaus are presented in the discharge process and one potential plateau is observed in the charge process. The charge/ discharge profiles show similar features and are well-consistent with the CV curves.

Fig. 3c and d show the rate performances of the $\mathrm{S} @ \mathrm{MnO}_{2} @ \mathrm{C}$ cathode under various current rates. The capacities decreased from $\sim 820.2$ to $703.3,602.3$, and $510.1 \mathrm{~mA} \mathrm{~h} \mathrm{~g}^{-1}$ when the current density was increased from 0.2 to $0.5,1.0$, and $2.0 \mathrm{C}$, respectively. It should be noted that a capacity of $\sim 510.1 \mathrm{~mA} \mathrm{~h} \mathrm{~g}^{-1}$ was still retained at a high current density of to $2.0 \mathrm{C}$, which is clearly higher than that of the $\mathrm{S} @ \mathrm{MnO}_{2}$ and $\mathrm{S} @ \mathrm{C}$ cathodes reported previously. ${ }^{35,36}$ After cycling at the high current density of $2.0 \mathrm{C}$ for 10 cycles, the capacity of about $784.8 \mathrm{~mA} \mathrm{~h} \mathrm{~g}{ }^{-1}$ was recovered as the current density was switched back to $0.2 \mathrm{C}$, corresponding to a capacity retention of $\sim 95.7 \%$, which indicates a high stability as well as an excellent reversibility of the electrode. Moreover, a distinct discharging plateau was still obtained at high rates (Fig. 3d), indicating the facile mass transport and reaction kinetics of the $\mathrm{S} @ \mathrm{MnO}_{2} @ \mathrm{C}$ cathode. The cycling stabilities of the $\mathrm{S} @ \mathrm{MnO}_{2} @ \mathrm{C}$ cathodes were tested by carrying out the discharge-charge measurements up to 100 cycles as shown in Fig. 3e. It should be noted that the test was performed at a low rate of $0.2 \mathrm{C}$ in the initial three cycles for the slow activation of $\mathrm{S} @ \mathrm{MnO}_{2} @ \mathrm{C}$. As shown in Fig. 3e, the $\mathrm{S} @ \mathrm{MnO}_{2} @ \mathrm{C}$ cathode delivered the discharge capacity of $593 \mathrm{~mA} \mathrm{~h} \mathrm{~g}^{-1}$ for the fourth cycle and it was able to maintain 

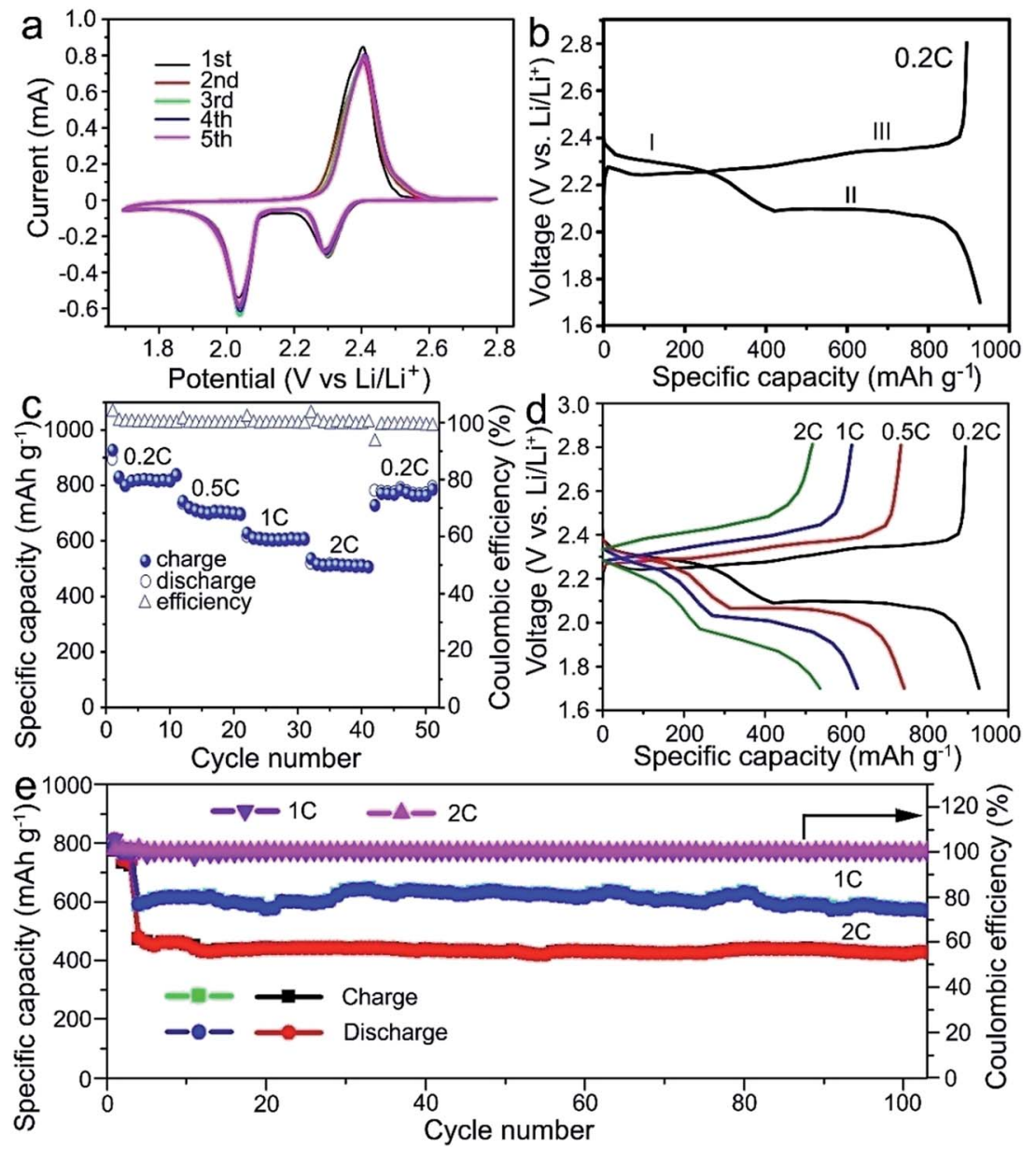

Fig. 3 (a) $\mathrm{CV}$ profiles of the $\mathrm{S} \mathrm{MnO}_{2} \mathrm{aC}$ electrode between the cut-off voltages of $1.7 \mathrm{~V}$ and $2.8 \mathrm{~V}$. (b) Charge and discharge curves of the $\mathrm{S}\left(\mathrm{MnO}_{2} \mathrm{aC}\right.$ electrode under the current density of $0.2 \mathrm{C}$. (c) Rating performance the $\mathrm{S}_{\mathrm{aMnO}} \mathrm{aC}$ electrode under different current rates. (d) Charge and discharge curves of the $\mathrm{S}_{\mathrm{aMnO}} \mathrm{aC}$ electrode under different current rates. (e) Cycling performance of the $\mathrm{S}\left(\mathrm{MnO} \mathrm{O}_{2} \mathrm{aC}\right.$ electrode under the current density of $1.0 \mathrm{C}$ and $2.0 \mathrm{C}$.

574.1 $\mathrm{mA} \mathrm{h} \mathrm{g}^{-1}$ in the 100th charge-discharge cycle at 1.0C, corresponding to a capacity retention of $96.8 \%$. In particular, at a high current density of $2.0 \mathrm{C}$, the discharge capacity of the $\mathrm{S} @ \mathrm{MnO}_{2} @ \mathrm{C}$ cathode was $476.7 \mathrm{~mA} \mathrm{~h} \mathrm{~g}^{-1}$ in the first cycle and it was able to maintain $426.9 \mathrm{~mA} \mathrm{~h} \mathrm{~g}^{-1}$ after 100 charge-discharge cycles at 2.0C. On average, the $\mathrm{S} @ \mathrm{MnO}_{2} @ \mathrm{C}$ cathode showed a capacity fading rate of only $0.1 \%$ per cycle, which is clearly smaller than those of previously reported $\mathrm{S} @ \mathrm{MnO}_{2}$ or S@Cbased cathodes. ${ }^{37,38}$ During the entire cycling at $2.0 \mathrm{C}$, the coulombic efficiency was higher than $99.7 \%$. As a control sample, $\mathrm{S} / \mathrm{MnO}_{2}$ composite cathodes were synthesized (Fig. S4 $\dagger$ ) and the rate performance and cyclic stability were also tested. The capacity of the $\mathrm{S} / \mathrm{MnO}_{2}$ composite decreased from 651.5 to 515.5, 444.6, and $382.4 \mathrm{~mA} \mathrm{~h} \mathrm{~g}{ }^{-1}$ when the current density was increased from 0.2 to $0.5,1.0$, and $2.0 \mathrm{C}$, respectively, which is significantly lower than those for the $\mathrm{S} @ \mathrm{MnO}_{2} @ \mathrm{C}$ cathode. After cycling at the high current density of $2.0 \mathrm{C}$, the capacity recovered to about $531 \mathrm{~mA} \mathrm{~h} \mathrm{~g}^{-1}$ as the current density was switched back to $0.2 \mathrm{C}$, corresponding to a capacity retention of $\sim 81.5 \%$, which indicates low reversibility of the electrode. In a sharp contrast to the $\mathrm{S} @ \mathrm{MnO}_{2} @ \mathrm{C}$ composite cathode, the capacity of the $\mathrm{S} / \mathrm{MnO}_{2}$ electrode declined drastically from $\sim 497.6 \mathrm{~mA} \mathrm{~h} \mathrm{~g}^{-1}$ in the fourth cycle to $381.6 \mathrm{~mA} \mathrm{~h} \mathrm{~g}^{-1}$ in the 100 th cycle, corresponding to a capacity retention of $\sim 76.6 \%$. Moreover, the coulombic efficiency of the cell was only 99.1$99.6 \%$, indicating its low electrochemical reversibility. The electrochemical results of the two electrodes clearly revealed that only the interaction of polysulfides with $\mathrm{MnO}_{2}$ nanomaterials is not enough to improve the sulfur cathode performance. ${ }^{18,39,40}$ Furthermore, $\mathrm{MnO}_{2}$ hollow spheres and carbon hollow spheres were synthesized (Fig. S5 $\dagger$ ) and $\mathrm{S} @ \mathrm{MnO}_{2}$ and S@C cathodes were formed to demonstrate the advantage of $\mathrm{S} @ \mathrm{MnO}_{2} @ \mathrm{C}$. The sulfur contents of the two samples were almost the same as that of the $\mathrm{S} @ \mathrm{MnO}_{2} @ \mathrm{C}$ electrode (Fig. S6 $†$ ). In addition, the cycling performance of the $\mathrm{S} @ \mathrm{MnO}_{2}$ and $\mathrm{S} @ \mathrm{C}$ electrodes was also investigated (Fig. S7 $\dagger$ ). The capacities of the $\mathrm{S} @ \mathrm{MnO}_{2}$ and $\mathrm{S} @ \mathrm{C}$ electrodes declined drastically from $\sim 415.7 \mathrm{~mA} \mathrm{~h} \mathrm{~g}^{-1}$ and $\sim 584.9 \mathrm{~mA} \mathrm{~h} \mathrm{~g}{ }^{-1}$ in the fourth cycle to $373.2 \mathrm{~mA} \mathrm{~h} \mathrm{~g}^{-1}$ and $311.6 \mathrm{~mA} \mathrm{~h} \mathrm{~g}^{-1}$ in the $100^{\text {th }}$ cycle under the current density of $1.0 \mathrm{C}$, respectively (Fig. S7†). The performances of both $\mathrm{S} @ \mathrm{MnO}_{2}$ and $\mathrm{S} @ \mathrm{C}$ electrodes were worse than that of $\mathrm{S} @ \mathrm{MnO}_{2} @ \mathrm{C}$. 

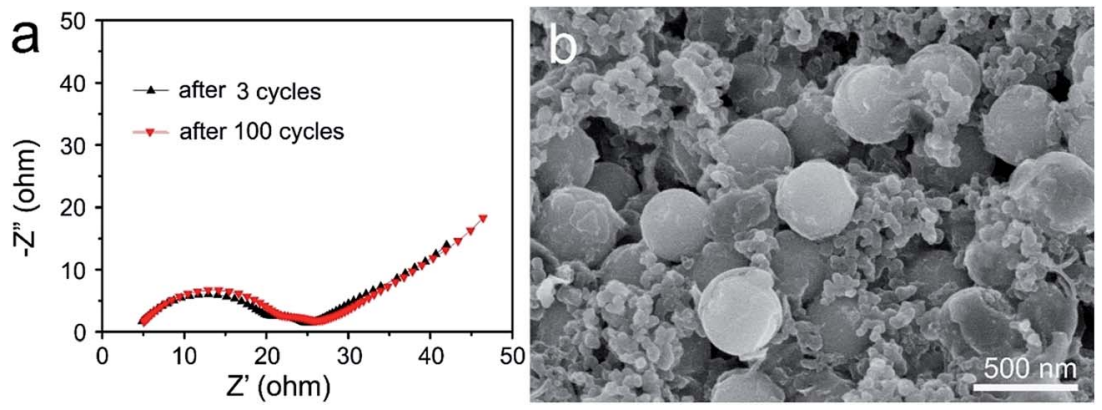

Fig. 4 (a) Nyquist plots of the $\mathrm{S} \mathrm{MnO}_{2} \mathrm{aC}$ hybrid nanospheres electrode measured at an amplitude of $5 \mathrm{mV}$ over a frequency range from 100 $\mathrm{kHz}$ to $0.01 \mathrm{~Hz}$ after 3 cycles and 100 cycles. (b) SEM image of the $\mathrm{S} \mathrm{MnO}_{2} \mathrm{aC}$ hybrid nanospheres-based electrode after $100 \mathrm{cycles}$ at $2.0 \mathrm{C}$.

To understand the significant increase in the electrochemical performance, the electrochemical impedance spectra (EIS) of the $\mathrm{S} @ \mathrm{MnO}_{2} @ \mathrm{C}$ electrode was first collected before and after 100 cycles as shown in Fig. 4a. The Nyquist plots of both samples depict a semicircle in the high-to-medium frequency region and an inclined line at the low frequency region. The semicircle is attributed to the charge transfer process at the electrode/electrolyte interface and the inclined line corresponds to the lithium ion-diffusion process into the bulk of the electrode, which is known as the Warburg diffusion. ${ }^{41}$ The impedance parameter of the $\mathrm{S}_{\mathrm{MnO}_{2}} @ \mathrm{C}$ electrode shows a minimum change between values before and after 100 cycles, indicating good electrochemical kinetics of these composite electrodes. Such minor change in charge transfer resistance upon cycling indicated a relatively stable electrode-electrolyte interface and provided significant advantages of rapid electron transport and fast faradic reaction during the electrochemical lithium insertion/extraction processes, which is favorable for increased capacity and good cycle performance. In addition, the morphologies of the $\mathrm{S} @ \mathrm{MnO}_{2} @ \mathrm{C}$ hybrid nanospheres before and after 100 cycles at $2.0 \mathrm{C}$ were also examined by SEM (Fig. $4 \mathrm{~b}$ and $\mathrm{S} 8 \dagger$ ). It was found that the $\mathrm{S} @ \mathrm{MnO}_{2} @ \mathrm{C}$ electrode was well preserved without any apparent destruction, crack and joint points as compared to that before cycling, demonstrating the advantages of rapid charge transfer among active materials, conductive carbon and binders during the electrochemical lithium insertion/extraction processes as shown in Fig. S8..$^{42}$ Moreover, it was also found that the $\mathrm{S} @ \mathrm{MnO}_{2} @ \mathrm{C}$ hybrid nanospheres were well preserved without any apparent destruction as indicated by the high magnification SEM image (Fig. 4b), indicating that the insertion and extraction of the lithium ion had no distinct impact on the composite structures because sufficient free space was available for the expansion of the loaded S nanoparticles inside the $\mathrm{S} @ \mathrm{MnO}_{2} @ \mathrm{C}$ hybrid nanospheres. Finally, the thin $\mathrm{MnO}_{2}$ layer between the $\mathrm{S}$ nanoparticles and $\mathrm{C}$ hollow spheres is an efficient sulfur adsorption layer, which can provide a much larger contact area for the mitigation of polysulfide dissolution owing to the strong interactions between $\mathrm{MnO}_{2}$ and the polysulfides and promote stable redox activity to suppress the shuttle effect during the cycling. In addition, encapsulation of sulfur of the porous carbon layer also prevents intermediate product polysulfides from outflowing into the electrolyte. Therefore, the hollow dual- shell sphere of $\mathrm{MnO}_{2}$ layer and $\mathrm{C}$ layer spheres increases the effectiveness of preventing polysulfide dissolution, accommodates volumetric expansion in discharge cycling and also facilitates ion and electron transport, which improves cycle stability. The unique material composition, morphology and structure of the $\mathrm{S} @ \mathrm{MnO}_{2} @ \mathrm{C}$ hybrid nanospheres-based electrode resulted in its good specific capacity, excellent cycling stability and high rate performance.

\section{Conclusion}

In summary, we demonstrated a facile and effective method for the synthesis of $\mathrm{S} @ \mathrm{MnO}_{2} @ \mathrm{C}$ hybrid nanospheres. The hollow C nanospheres not only provide highly efficient pathways for fast electron/ion transfer, but also prevent rapid dissolution of polysulfides into the electrolyte. The $\mathrm{MnO}_{2}$ layer offers chemical adsorption to polysulfides and restricts the polysulfides from dissolving into the electrolyte. Moreover, the sufficient voids provide extra space for the expansion of the encapsulated sulfur nanoparticles. With this advanced design, the $\mathrm{S} @ \mathrm{MnO}_{2} @ \mathrm{C}$ electrode shows high capacity, high coulombic efficiency and an excellent cycling stability. At a high current density of 1.0C, the capacity of the $\mathrm{S} @ \mathrm{MnO}_{2} @ \mathrm{C}$ cathode was $593 \mathrm{~mA} \mathrm{~h} \mathrm{~g}{ }^{-1}$ in the fourth cycle and it was able to maintain $574.1 \mathrm{~mA} \mathrm{~h} \mathrm{~g}^{-1}$ in the 100 th cycle at $1.0 \mathrm{C}$, corresponding to a capacity retention of $96.6 \%$. The obtained results of the $\mathrm{S} @ \mathrm{MnO}_{2} @ \mathrm{C}$ cathode make it a promising cathode material for lithium-sulfur batteries for power-intensive energy storage applications.

\section{Conflicts of interest}

There are no conflicts to declare.

\section{Acknowledgements}

This study was financially supported by the National Natural Science Foundation of China (Grant No. 51672044, 51741203 and 51472049), the Shanghai Pujiang Program (Grant No. 16PJ1400200), the Shanghai Sailing Program (Grant No. 17YF1400300), the Program for Innovative Research Team in University of Ministry of Education of China (IRT_16R13), the DHU Distinguished Young Professor Program, and the Fundamental Research Funds for the Central Universities. 


\section{References}

1 A. Manthiram, Y. Fu, S.-H. Chung, C. Zu and Y.-S. Su, Chem. Rev., 2014, 114, 11751.

2 P. G. Bruce, S. A. Freunberger, L. J. Hardwick and J.-M. Tarascon, Nat. Mater., 2011, 11, 19.

3 X. Ji, K. T. Lee and L. F. Nazar, Nat. Mater., 2009, 8, 500.

4 Y. Wang and G. Cao, Adv. Mater., 2008, 20, 2251.

5 E. Hosono, T. Kudo, I. Honma, H. Matsuda and H. Zhou, Nano Lett., 2009, 9, 1045.

6 L.-X. Yuan, Z.-H. Wang, W.-X. Zhang, X.-L. Hu, J.-T. Chen, Y.-H. Huang and J. B. Goodenough, Energy Environ. Sci., 2011, 4, 269.

7 L. Xiao, Y. Cao, J. Xiao, B. Schwenzer, M. H. Engelhard, L. V. Saraf, Z. Nie, G. J. Exarhos and J. Liu, Adv. Mater., 2012, 24, 1176.

8 S. Evers and L. F. Nazar, Acc. Chem. Res., 2013, 46, 1135.

9 X. Liu, J.-Q. Huang, Q. Zhang and L. Mai, Adv. Mater., 2017, 29, 1601759.

10 C. Zhang, H. B. Wu, C. Yuan, Z. Guo and X. W. Lou, Angew. Chem., Int. Ed., 2012, 51, 9592.

11 G. He, X. Ji and L. Nazar, Energy Environ. Sci., 2011, 4, 2878. 12 J. Zhang, C.-P. Yang, Y.-X. Yin, L.-J. Wan and Y.-G. Guo, Adv. Mater., 2016, 28, 9539.

13 X. Tao, J. Wang, Z. Ying, Q. Cai, G. Zheng, Y. Gan, H. Huang, Y. Xia, C. Liang, W. Zhang and Y. Cui, Nano Lett., 2014, 14, 5288.

14 Q. Pang, D. Kundu and L. F. Nazar, Mater. Horiz., 2016, 3, 130.

15 X. Liang, C. Hart, Q. Pang, A. Garsuch, T. Weiss and L. F. Nazar, Nat. Commun., 2015, 6, 5682.

16 S. Rehman, T. Tang, Z. Ali, X. Huang and Y. Hou, Small, 2017, 13, 1700087.

17 T. Chen, L. Ma, B. Cheng, R. Chen, Y. Hu, G. Zhu, Y. Wang, J. Liang, Z. Tie, J. Liu and Z. Jin, Nano Energy, 2017, 38, 239.

18 J. Shen, J. Liu, Z. Liu, R. Hu, J. Liu and M. Zhu, Chem.-Eur. J., 2018, 24, 1.

19 X. Liang and L. F. Nazar, ACS Nano, 2016, 10, 4192.

20 Z. Seh, Y. Sun, Q. Zhang and Y. Cui, Chem. Soc. Rev., 2016, 45, 5605.

21 H. Kim, J. T. Lee, A. Magasinski, K. Zhao, Y. Liu and G. Yushin, Adv. Energy Mater., 2015, 5, 1501306.
22 K. Chang, W. Chen, L. Ma, H. Li, H. Li, F. Huang, Z. Xu, Q. Zhang and J.-Y. Lee, J. Mater. Chem., 2011, 21, 6251.

23 Y. Umezawa and C. N. Reilley, Anal. Chem., 1978, 50, 1290.

24 V. Di Castro and G. Polzonetti, J. Electron Spectrosc. Relat. Phenom., 1989, 48, 117.

25 T. Ji, Q. Liu, R. Zou, Y. Sun, K. Xu, L. Sang, M. Liao, Y. Koide, L. Yu and J. Hu, Adv. Funct. Mater., 2016, 26, 1400.

26 S.-R. Chen, Y.-P. Zhai, G.-L. Xu, Y.-X. Jiang, D.-Y. Zhao, J.-T. Li, L. Huang and S.-G. Sun, Electrochim. Acta, 2011, 56, 9549.

27 S. S. Zhang, J. Power Sources, 2013, 231, 153.

28 J.-Q. Huang, Q. Zhang, H.-J. Peng, X.-Y. Liu, W.-Z. Qian and F. Wei, Energy Environ. Sci., 2014, 7, 347.

29 M.-Q. Zhao, Q. Zhang, J.-Q. Huang, G.-L. Tian, J.-Q. Nie, H.-J. Peng and F. Wei, Nat. Commun., 2014, 5, 3410.

30 G. C. Li, J. J. Hu, G. R. Li, S. H. Ye and X. P. Gao, J. Power Sources, 2013, 240, 598.

31 W. Deng, A. Hu, X. Chen, S. Zhang, Q. Tang, Z. Liu, B. Fan and K. Xiao, J. Power Sources, 2016, 322, 138.

32 G. Zhou, L.-C. Yin, D.-W. Wang, L. Li, S. Pei, I. R. Gentle, F. Li and H.-M. Cheng, ACS Nano, 2013, 7, 5367.

33 S. Xin, Y.-X. Yin, Y.-G. Guo and L.-J. Wan, Adv. Mater., 2014, 26, 1261.

34 Y. Qiu, W. Li, G. Li, Y. Hou, L. Zhou, H. Li, M. Liu, F. Ye, X. Yang and Y. Zhang, Nano Res., 2014, 7, 1355.

35 S. A. Ahad, P. Ragupathy, S. Ryu, H.-W. Lee and D. K. Kim, Chem. Commun., 2017, 53, 8782.

36 C. Zhang, H. B. Wu, C. Yuan, Z. Guo and X. W. Lou, Angew. Chem., 2012, 124, 9730.

37 Y.-S. Su and A. Manthiram, Nat. Commun., 2012, 3, 1166.

38 L. Ni, Z. Wu, G. Zhao, C. Sun, C. Zhou, X. Gong and G. Diao, Small, 2017, 13, 1603466.

39 X. Liang, C. Hart, Q. Pang, A. Garsuch, T. Weiss and L. F. Nazar, Nat. Commun., 2015, 6, 5682.

40 S. Rehman, T. Tang, Z. Ali, X. Huang and Y. Hou, Small, 2017, 13, 1700087.

41 Z. Deng, Z. Zhang, Y. Lai, J. Liu, J. Li and Y. Liu, J. Electrochem. Soc., 2013, 160, A553.

42 P. Gao, J. Fu, J. Yang, R. Lv, J. Wang, Y. Nuli and X. Tang, Phys. Chem. Chem. Phys., 2009, 11, 11101. 